\title{
Article
}

\section{Development of an Analytical Methodology for Chemical Profile of Cocaine seized in Rio de Janeiro, Brazil}

\author{
Wagner Felippe Pacheco ${ }^{1 *}$, Vanessa Gomes Kelly Almeida ${ }^{2}$, Ricardo J. Cassella ${ }^{1}$, \\ Fábio Grandis Lepri ${ }^{1}$ \\ ${ }^{1}$ Instituto de Química, Universidade Federal Fluminense, Outeiro São João Batista s/n, \\ Centro, Niterói, RJ, Brazil. ZIP 24020-141 \\ ${ }^{2}$ Departamento de Química, Universidade Federal Rural do Rio de Janeiro, \\ Rodovia BR 465, Km 07 - Zona Rural, Seropédica, RJ, Brazil. ZIP 23890-000
}

\section{Graphical Abstract}
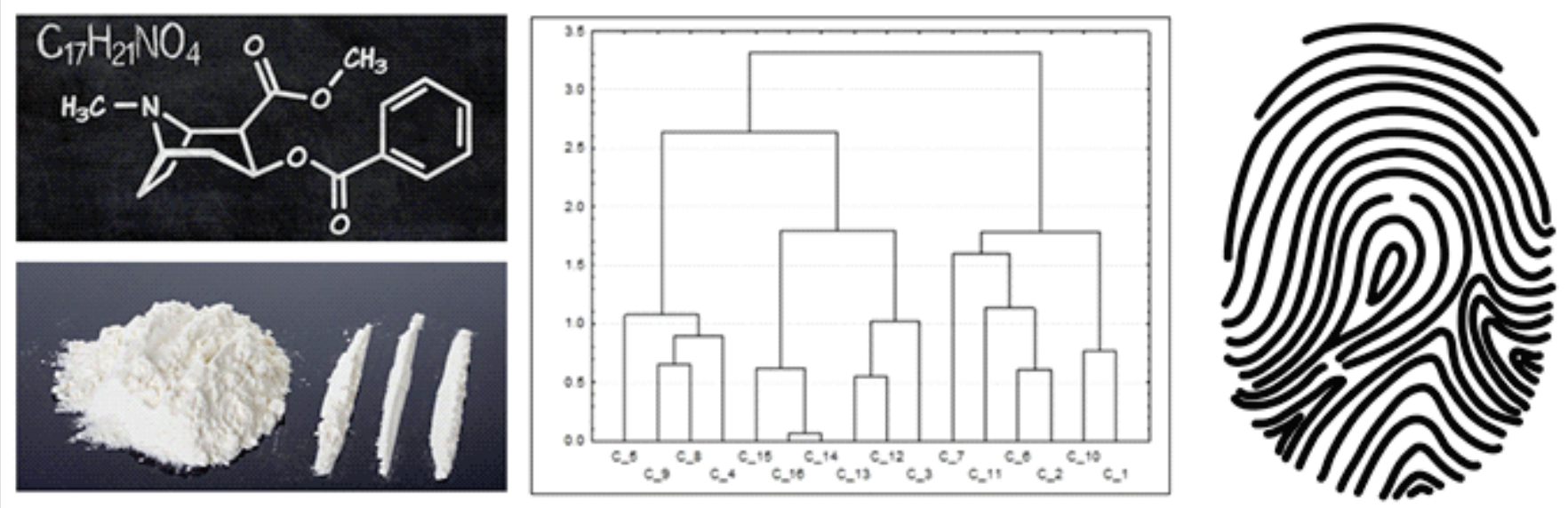

A hierarchical cluster analysis, which could be used to obtain important information regarding the origin and distribution network of cocaine, was created from data on cocaine content and concentrations of main contaminants and adulterants.

This work presents the development of analytical methodologies to determine cocaine, its major adulterants (acetaminophen, diltiazem, caffeine, lidocaine and phenacetin), lead and manganese in 17 samples of cocaine-derived drugs seized by the Civil Police of the state of Rio de Janeiro, Brazil, during the year 2013. Cocaine and major adulterants were determined by high-performance liquid chromatography with diode array detection (HPLC-DAD), whereas the inorganic contaminants were determined by graphite furnace atomic absorption spectrometry (GFAAS). Approximately $80 \%$ of the analyzed samples contained at least one adulterant above the limit of quantification, whereas metals ( $\mathrm{Pb}$ and/or $\mathrm{Mn}$ ) did in almost all the samples. The data obtained from the small set of analyzed samples allowed the application of a hierarchical cluster analysis (HCA), which indicated that the samples could be classified according to their chemical composition.

Keywords: Cocaine, characterization, hierarchical cluster analysis, adulterants.

\section{INTRODUCTION}

One of the most critical problems that affects modern society is the illicit consumption of drugs, such as marijuana, cocaine and others. Nowadays, this problem is a major public, social, economic and legal concern. The consumption of drugs moves billions of dollars per year, consisting of an illicit market not only in Brazil, but also in many other countries. According to the World Drug Report of 2015 [1], it is estimated that approximately 246 million people, about $5.0 \%$ of the adult world population, had used an 
illicit drug at least once in the year 2010. The document also reports that the consumption of cocaine remained stable among the population aged between 15 and 64 years (approximately 19 million users) and that there was an increase in consumption of drugs in Brazil.

Brazil is not considered one of the biggest producers of cocaine, but due to its strategic location in South America and vast border area, figures as an important route for the distribution of the drug. Cocaine is produced mainly in Colombia, Peru and Bolivia and is sent to Europa and Africa through Brazilian ports and airports. Besides serving as a route for drug trafficking, Brazil is a large consumer market. A direct consequence of the high consumption is the illegal cocaine trafficking, which generates high rates of urban violence (territorial disputes between rival groups and clashes with security forces, among other types of crime), a daily problem that occurs especially in the metropolitan region of Rio de Janeiro city, in Brazil [2].

Several actions have been taken by the Brazilian government to suppress drug trafficking and reduce the violence caused by such trafficking. However, these actions have not yet reached the desired effect. Among the most effective actions observed in other countries, actions involving intelligence and forensics have proven to be the most effective in combating crime and trafficking. Within this scope, drug profiling can be highlighted as a powerful tool in combating drug trafficking [3-7].

Whether of natural origin (such as heroin, cocaine or marijuana) or synthetic (such as amphetamine), illicit drugs are such a complex mixture that they are rarely found as chemical-pharmaceutical products in their pure form. The clandestine process of production of drugs generates a chemical signature in the final product from of all the supplies and materials used in the production. These materials are present as impurities, and in the case of trace elements, they are unintentionally introduced in the production process, or as excipients purposely added during the production of the drug [4].

From the standpoint of chemical composition, the substances present in illicit cocaine may be classified into three main groups: (1) natural components that are co-extracted from the raw material of the drug (as alkaloids present in the coca plant); (2) parallel products generated during the various stages of synthesis/ extraction/dilution of the drug; (3) other products deliberately added to the final composition of the drug in order to dilute the active ingredient and increase the profits of drug dealers, giving rise to a broad range of concentration of cocaine in the final product, a parameter which can be easily monitored and used to characterize the drug [5].

The chemical analysis of seized cocaine can provide important information for the guidance of security forces. From an investigative perspective, the chemical profiling of drugs can allow to three main actions: (1) establish correlation among samples; (2) classify the seized drug into different classes of samples to facilitate processing and quantification of networks and drug delivery and; (3) identify the source of drug a clandestine laboratory or a geographical region where the raw material was obtained [5].

Papers have been published about the development and/or application of analytical methods for obtaining the chemical profile of drugs seized in different regions. Most of them are based on gas chromatography-mass spectrometry (GC-MS) [4-7] as recommended in the manuals of the United Nations Office on Drugs and Crime (UNODC) [1]. High-performance liquid chromatography (HPLC) associated with mass spectrometry (HPLC-MS) has also been employed. However, this is a more costly and technically complex technique, which requires skilled labor for conducting the analysis. The use of cheaper and more widespread detectors, such as UV detectors, are advisable because they provide sufficient sensitivity, are easy to operate and are readily available in analytical laboratories. HPLC-UV there are not no difficulties related to the volatility and thermal stability of the analytes, leading an excellent separation of compounds. Moreover, the use of the HPLC-UV technique saves time and requires no complex steps of sample preparation [6].

Although there are many studies about the quantification of contaminants of cocaine seized in different countries [7-19], less works on the quantification of cocaine, adulterants and contaminants in samples seized in Brazil have been published. Goulart Jr. [20] determined the cocaine content and the main adulterants in samples of cocaine supplied by the Brazilian Federal Police, which were seized in different regions of Brazil in 2009 to 2011. The samples were analyzed using gas chromatography with a flame 


\section{Article}

ionization detector (GC-FID) and the concentrations of cocaine found ranged from $1.43 \%$ up to $97.08 \%$, with an average concentration of $65 \%$ in terms of mass. The contaminants found in the samples were phenacetin, lidocaine, caffeine, diltiazem, hydroxyzine, benzocaine and levamisole.

Floriani et al. [3] developed a methodology for the simultaneous determination of cocaine and main contaminants (caffeine, lidocaine, phenacetin, benzocaine and diltiazem) in samples provided by the Institute of Criminology of Paraná (Brazil), using high performance liquid chromatography system with a diode array detector (HPLC-DAD). The samples were seized between 2007 and 2012 and approximately $71 \%$ of them had noticeable concentrations of caffeine, lidocaine, phenacetin, benzocaine and diltiazem.

Bernardo et al. [21] analyzed drug samples seized in Minas Gerais state, Brazil, during the year 2001. Approximately $90 \%$ of the samples contained cocaine, $50.2 \%$ of the samples presented caffeine, $65 \%$ presented lidocaine and $11 \%$ presented prilocaine. The identification of cocaine and adulterants was carried out by thin layer chromatography, whereas quantification was by GC-FID.

Carvalho and Mídio [22] reported the presence of lidocaine, procaine and caffeine as the main adulterants in samples of cocaine seized in the city of São Paulo (Brazil) in 1997. The samples had a cocaine content ranging from 20 to $70 \%$.

Oliveira [23] employed HPLC-UV to determine the content of cocaine in samples seized by the police. The results indicated the presence of cocaine in all samples, with levels ranging from $37.4 \%$ to $95.6 \%$ in terms of mass.

Magalhães et al. [24] developed a CG-MS method to quantify cocaine, caffeine, lidocaine and benzocaine in street cocaine samples seized in two different states of Brazil (Minas Gerais and Amazonas) in July 2008 to May 2010. They found different concentrations of cocaine and adulterants in the samples from each region. De Souza et al. [25] also used CG-MS to quantify cocaine, caffeine and lidocaine in cocaine seized in the state of Espírito Santo, Brazil, in samples collected in the years 2008 to 2012.

Lapachinske et al. [26] employed gas chromatography with nitrogen-phosphorus detector (GC-NPD) for the quantification of cocaine, caffeine, 4-dimethylaminoantipyrine, levamisole, lidocaine and phenacetin in illicit samples. The method was successfully applied to drug samples seized by the Brazilian Federal Police in the International Airport of Sao Paulo and mailing services during the year 2011.

More recently, the determination of cocaine on banknotes in circulation in the metropolitan area of Rio de Janeiro has been published. It was observed that more than $80 \%$ of the banknotes presented detectable amounts of cocaine. However, typical cocaine adulterants in the banknotes were not investigated [31].

Although it is less common than the organic content analyses, there are some works in literature dealing with the inorganic composition of seized drugs. In this case the detection is usually based on atomic emission or absorption spectrometry, or mass spectrometry [28-30].

The main objective of the present work was to develop analytical methodologies for the determination of cocaine and the major adulterants (acetaminophen, diltiazem, caffeine, lidocaine and phenacetin) by HPLC-DAD, and some inorganic contaminants (lead and manganese) by graphite furnace atomic absorption spectrometry (GFAAS) in samples of cocaine seized by the police in Rio de Janeiro, Brazil, in 2013. The concentrations of these substances were employed to classify the samples in different groups according to their chemical composition. To do so, a hierarchical cluster analysis (HCA) was applied, providing a tool that can be used by public security forces to investigate possible drug sources.

\section{MATERIALS AND METHODS Apparatus and instruments}

The determination of the major adulterants was carried out with an Ultimate 3000 (Dionex, Sunnyvale, CA, USA) high-performance liquid chromatography system equipped with a diode-array detector. A Zorbax 300SB-C18 (Agilent, Santa Clara, CA, USA) analytical column $(150 \times 2.1 \mathrm{~mm}, 5 \mu \mathrm{m}$ particle size) was employed for the separation of the analytes.

The determination of $\mathrm{Pb}$ and Mn was carried out by GF AAS using a Varian (Mulgrave, Australia) graphite furnace atomic absorption spectrometer, model AA240Z, equipped with a Varian GTA 120 longitudinally heated atomizer unit and a Varian PSD 120 auto sampler. Graphite tubes with integrated 
platform (Varian part no. 63-100026-00) were used and all measurements were in integrated absorbance mode. Background correction was performed with a polarized Zeeman-effect with a transverse magnetic field, operated at a constant magnetic field strength of $0.8 \mathrm{~T}$. Lead and $\mathrm{Mn}$ were measured at $283.3 \mathrm{~nm}$ and $279.5 \mathrm{~nm}$, respectively, whereas the spectral bandwidth was $0.2 \mathrm{~nm}$. Individual hollow cathode lamps of $\mathrm{Pb}$ and $\mathrm{Mn}$, operated at $7.0 \mathrm{~mA}$ and $5.0 \mathrm{~mA}$, respectively, were employed as radiation sources.

To filter the solutions before injecting into the chromatographic system, a NylonTM membrane $(47 \mathrm{~mm}$, $0.45 \mu \mathrm{m}$ pore diameter) from Unifil (São Paulo, Brazil) was used.

Standards and samples were weighed using an analytical scale from Shimadzu, model AUY220 (Tokyo, Japan), and the $\mathrm{pH}$ measurements were performed with a DM-22 pH meter from Digimed (São Paulo, Brazil).

Solutions were homogenized with a vortex shaker, model 52K, from CAEL (Rio de Janeiro, Brazil). The removal of air bubbles from the solutions was performed with the aid of an ultrasonic bath (frequency of $40 \mathrm{KHz}$ ) supplied by Unique (São Paulo, Brazil), model Ultracleaner 1600.

The solid-phase extraction was conducted using Phenomenex (USA) Strata ${ }^{\mathrm{TM}}-\mathrm{X} 33$ um polymeric reversed phase cartridges, containing $60 \mathrm{mg} \mathrm{mL}^{-1}$ of solid phase. The hierarchical cluster analysis was performed with Statistica software version 3.0.

\section{Reagents and solutions}

The deionized water employed in this work was purified in a Millipore Direct-Q 3 (Milford, USA) system to achieve a resistivity of at least $18.2 \mathrm{M} \Omega \mathrm{cm}$.

Acetonitrile, methanol, ethanol and acetone were all HPLC grade and were supplied by Tedia (Fairfield, $\mathrm{OH}, \mathrm{USA}$ ). Glacial acetic acid used in the preparation of the buffer solution was supplied by Vetec (Rio de Janeiro, Brazil).

A $1000 \mathrm{mg} \mathrm{L}^{-1}$ standard solution of cocaine was purchased from Cerillant (Round Rock, TX, USA) in ampoules containing $1 \mathrm{~mL}$ of acetonitrile. The diluted standard solutions of cocaine were prepared in 10 $\mathrm{mL}$ volumetric flasks, by suitable dilution of the $1000 \mathrm{mg} \mathrm{L}^{-1}$ stock solution with acetonitrile.

Solid standards of caffeine, diltiazem, acetaminophen, phenacetin and lidocaine were purchased from Sigma-Aldrich. Stock solutions $200 \mathrm{mg} \mathrm{L}^{-1}$ of these substances were prepared, separately, in $100 \mathrm{~mL}$ flasks by dissolving $20 \mathrm{mg}$ of each standard in $0.01 \% \mathrm{v} / \mathrm{v}$ acetate buffer solution with $\mathrm{pH} 3.9$. Diluted solutions of caffeine, diltiazem, acetaminophen, phenacetin and lidocaine solutions were prepared in $10 \mathrm{~mL}$ volumetric flasks by appropriate dilution of the $200 \mathrm{mg} \mathrm{L}^{-1}$ stock solution with $0.01 \% \mathrm{v} / \mathrm{v}$ acetate buffer solution of with 3.9 .

Stock standard solutions containing $1000 \mathrm{mg} \mathrm{L}^{-1}$ of $\mathrm{Mn}$ or $\mathrm{Pb}$ and also $\mathrm{HNO}_{3} 65 \% \mathrm{~m} / \mathrm{m}$ were purchased from Tedia (São Paulo, Brazil). Calibration solutions were prepared by appropriate dilution of the $1000 \mathrm{mg}$ $\mathrm{L}^{-1}$ stock solutions of each metal in $1 \% \mathrm{v} / \mathrm{v} \mathrm{HNO}_{3}$ solution in $10 \mathrm{~mL}$ volumetric flasks. Palladium modifier solution $10.000 \mathrm{mg} \mathrm{L}^{-1}$ was purchased from Merck (Darmstadt, Germany).

\section{Preparation of samples for the determination of cocaine and adulterants by HPLC-DAD}

All samples analysed in this work were provided by the Institute of Criminology Carlos Eboli (ICCE) of the Civil Police of the State of Rio de Janeiro, Brazil. The extraction of cocaine and adulterants (diltiazem, acetaminophen, phenacetin and the lidocaine) from the samples was carried out by mixing 50 mg of each sample with $25 \mathrm{~mL}$ of a $1.7 \mathrm{mmol} \mathrm{L}^{-1}$ acetate buffer solution $(\mathrm{pH}=3.9)$, in a $50 \mathrm{~mL}$ capped polyethylene tube. The mixture was agitated for $10 \mathrm{~min}$ with the aid of a vortex mixer and the obtained solution was percolated $(5.0 \mathrm{~mL})$ through a Strata-X (polymeric reversed phase) cartridge in order to retain the target compounds and eliminate possible interferents. This procedure provided a convenient clean-up of the sample solution before its injection into the chromatographic system. The cartridges were previously conditioned with $5 \mathrm{~mL}$ of a $1.7 \mathrm{mmol} \mathrm{L}^{-1}$ acetate buffer solution $(\mathrm{pH}=3.9)$, and the elution was conducted with $2 \mathrm{~mL}$ of acetonitrile. The obtained extract was properly diluted for $5.0 \mathrm{~mL}$ with $1.7 \mathrm{mmol} \mathrm{L}^{-1}$ acetate buffer solution $(\mathrm{pH}=3.9)$ prior to its injection into the chromatographic system. 


\section{Article}

\section{Chromatographic determination of cocaine and adulterants}

The quantification of cocaine and adulterants was carried out by injecting $20 \mu \mathrm{L}$ of the treated extract (sample or standard) into the chromatographic system, using a mixture of acetonitrile and acetic acid solution (1.7 mmol L-1) as mobile phase. The mobile phase was pumped at a flow rate of $1.0 \mathrm{~mL} \mathrm{~min}^{-1}$ and the elution was performed in gradient mode. The temperature of the column was set at $25^{\circ} \mathrm{C}$. The gradient of the mobile phase started with $10 \%$ acetonitrile, which increased to $50 \%$ over $20 \mathrm{~min}$. After finishing the chromatographic run, the proportion of acetonitrile returned to the initial condition $(10 \%)$ in order to allow the injection of a new extract aliquot.

\section{Sample preparation for Mn and Pb determination by GFAAS}

The sample preparation for $\mathrm{Mn}$ and $\mathrm{Pb}$ quantification consist of dissolving $25 \mathrm{mg}$ of sample in $5 \mathrm{~mL}$ of a $30 \% \mathrm{v} / \mathrm{v} \mathrm{HNO}_{3}$ solution; aliquots of the obtained solution were diluted with deionized water before their introduction into the graphite tube. In general, the samples solutions were diluted 1:100 and 1:20 for the measurement of $\mathrm{Mn}$ and $\mathrm{Pb}$, respectively.

The analytes were determined by introducing $20 \mu \mathrm{L}$ of the solution (sample or calibration solution) into the platform of the graphite tube and running the temperature program given in Table I, which was optimized in the present work. In the case of $\mathrm{Pb}, 10 \mu \mathrm{L}$ of a $1000 \mathrm{mg} \mathrm{L}^{-1} \mathrm{Pd}\left(\mathrm{NO}_{3}\right)_{2}$ solution as chemical modifier was co-injected with calibration or sample solutions.

Table I. Heating program employed for the measurement of Mn and Pb by GFAAS.

\begin{tabular}{|c|c|c|c|c|}
\hline Step & $\begin{array}{c}\text { Temperature } \\
\left({ }^{\circ} \mathrm{C}\right)\end{array}$ & $\begin{array}{c}\text { Ramp } \\
\text { (s) }\end{array}$ & $\begin{array}{c}\text { Hold } \\
\text { (s) }\end{array}$ & $\begin{array}{c}\text { Ar flow rate } \\
\left(\mathrm{mL} \mathrm{min}^{-1}\right)\end{array}$ \\
\hline Drying & $\begin{array}{l}50 \\
120\end{array}$ & $\begin{array}{c}5 \\
40\end{array}$ & $\begin{array}{c}0 \\
10\end{array}$ & $\begin{array}{l}300 \\
300\end{array}$ \\
\hline Pyrolysis & $\begin{array}{l}1200(\mathrm{Mn}) \\
1000(\mathrm{~Pb}) \\
\end{array}$ & 1 & 6 & 300 \\
\hline Atomization & $\begin{array}{l}1800(\mathrm{Mn}) \\
2200(\mathrm{~Pb})\end{array}$ & 1 & 3 & 0 \\
\hline Cleaning & $\begin{array}{l}2000(\mathrm{Mn}) \\
2300(\mathrm{~Pb})\end{array}$ & 2 & 0 & 300 \\
\hline
\end{tabular}

\section{Evaluation of the solubility of the samples}

Among the 17 samples analyzed in this work eight of them were used in the solubility test. Samples with different forms of distribution were selected.

The solubility test was performed by mixing $50 \mathrm{mg}$ of each sample with $10 \mathrm{~mL}$ of six different solvents/ solutions (methanol, acetonitrile, water, $0.01 \% \mathrm{v} / \mathrm{v}$ acetate buffer solution with $\mathrm{pH}=3.9,6 \mathrm{~mol} \mathrm{~L}^{-1} \mathrm{HCl}$ and $7 \mathrm{~mol} \mathrm{~L}^{-1} \mathrm{HNO}_{3}$ ) in a $15 \mathrm{~mL}$ capped polyethylene tube. The obtained mixtures were agitated with the aid of a vortex mixer in order to achieve maximum solubilization of the samples. All samples were highly soluble in only $\mathrm{HCl}$ and acetate buffer solutions. Therefore, acetate buffer solution was chosen as one of the solvents for the mobile phase used in the chromatographic system.

\section{RESULTS AND DISCUSSION}

\section{Development of the HPLC-DAD method for cocaine and adulterants determination}

The development of the chromatographic method for the determination of cocaine and adulterants (caffeine, diltiazem, lidocaine, acetaminophen and phenacetin) was carried out using a test solution containing $5.0 \mathrm{mg} \mathrm{L}^{-1}$ of each analyte, prepared in $1.7 \mathrm{mmol} \mathrm{L}^{-1}$ acetic acid solution at $\mathrm{pH} 3.9$. The initial chromatographic conditions were those cited on the certificate of the cocaine standard, where the use of

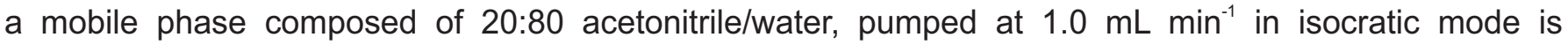
recommended. The temperature of the column was $30^{\circ} \mathrm{C}$ and the injection volume $20 \mu \mathrm{L}$. In this condition, a convenient resolution was not achieved, strong overlapping of the peaks was observed. However, suitable resolution of the chromatographic peaks was achieved using a mobile phase containing acetonitrile and acetic acid solution $\left(1.7 \mathrm{mmol} \mathrm{L}^{-1}, \mathrm{pH}=3.9\right)$ in gradient mode. (For details, see the experimental section). 
Once chromatographic conditions that allowed suitable separation of the substances of interest were established, the method was evaluated to identify possible interferent substances in the samples. Direct analysis of the sample solutions obtained by dissolution of the samples was not possible, because the presence of other compounds gave rise to a chromatogram with a large number of overlapped peaks. Some unknown substances co-eluted with the analytes, making impossible the quantification of the cocaine and the adulterants in the sample solutions. In order to solve this drawback, a solid phase extraction (SPE) procedure was evaluated for clean-up of the extracts before their injection into the chromatographic system. For such evaluation, test solutions of cocaine and adulterants were analysed. The SPE procedure was firstly tested for cocaine recovery of, the major substance present in the sample extracts. The results obtained in the recovery of cocaine are given in Table II.

Table II. Recovery test for cocaine using different solvents and solid-phase extraction

\begin{tabular}{lcc}
\hline \multirow{2}{*}{ Solvent } & \multicolumn{2}{c}{ Mass of cocaine $(\mu \mathbf{g})$} \\
\cline { 2 - 3 } & Added & Recovered \\
\hline Acetonitrile & 100.0 & 97.74 \\
Methanol & 100.0 & 89.2 \\
Water & 100.0 & 77.4 \\
$1.0 \times 10^{-3} \mathrm{~mol} \mathrm{~L}^{-1}$ of $\mathrm{HCl}$ & 100.0 & 57.4 \\
$1.0 \times 10^{-3} \mathrm{~mol} \mathrm{~L}^{-1}$ of $\mathrm{NaOH}$ & 100.0 & 33.6 \\
\hline $\mathrm{n}=3$ & &
\end{tabular}

As can be seen in Table II, quantitative recovery of cocaine was obtained when the extracts were cleaned-up by SPE and using acetonitrile (97.4\%) as eluent, evidencing that no losses of the analyte occurred during the clean-up procedure. Therefore, acetonitrile was chosen as eluent of cocaine. Afterwards, the same SPE procedure was evaluated for the recovery of the cocaine adulterants. Recovery ranging from 95.2 to $102 \%$ was observed using the same solid phase (Strata-X polymeric reversed cartridge) and the same eluent (acetonitrile), indicating that the proposed SPE procedure could be applied to clean-up the extracts. Figure 1 shows the chromatogram obtained for a sample extract enriched with cocaine and adulterants, which was treated using the SPE procedure. In Figure 1 it is possible to observe that a satisfactory resolution was achieved for all substances, which demonstrated the effectiveness of the SPE clean up. Therefore, this procedure could be applied in the analysis of the extracts obtained from the analyzed samples.

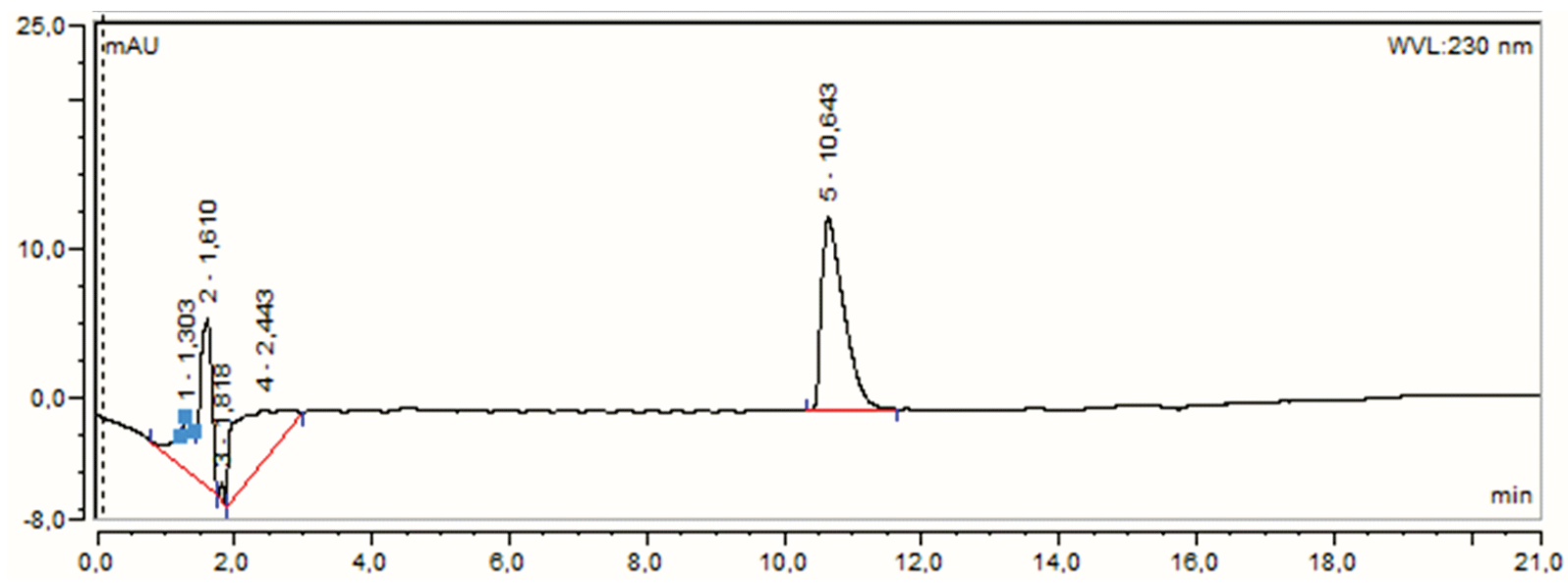

Figure 1. Typical chromatogram of a cocaine sample extract enriched with ( $5.0 \mathrm{mg} \mathrm{L}^{-1}$ of). 1: acetaminophen; 2: caffeine; 3: lidocaine; 4: phenacetin; 5: cocaine; 6: diltizazem. Wavelenght detection at $230 \mathrm{~nm}$; mobile phase: (A) acetonitrile (B) $1.7 \mathrm{mmol} \mathrm{L}^{-1}$ acetic acid solution, varying from $10 \%$ to $50 \% \mathrm{~A}$ in 20 minutes. 


\section{Article}

\section{Analytical characteristics of the HPLC method for the determination of cocaine and adulterants}

The analytical figures of merit (see Table III) of the method were obtained for all analytes (cocaine and adulterants) at the experimental conditions (sample preparation and measurement) evaluated and selected. The limits of detection (LOD) and quantification (LOQ) of the method were calculated, following the 3 (for LOD) and 10 (for LOQ) [34] using the standard deviation of the lower value of the analytical curve $\left(2.00 \mathrm{mg} \mathrm{L}^{-1}\right)$.

Table III. Figures of merit of the method for cocaine and adulterants determination by HPLC-DAD.

\begin{tabular}{|c|c|c|c|c|c|c|c|}
\hline Analyte & $\begin{array}{c}\text { Wave } \\
\text { length } \\
(\mathrm{nm})\end{array}$ & $\begin{array}{l}\text { Working } \\
\text { range } \\
\left(\mathrm{mg} \mathrm{L}^{-1}\right)\end{array}$ & $\begin{array}{l}\text { Typical linear } \\
\text { regression } \\
\text { equation of the } \\
\text { analytical curve }\end{array}$ & $r^{2}$ & $\begin{array}{l}\text { LOD } \\
\left(\mu g^{-1}\right)\end{array}$ & $\begin{array}{c}\mathrm{LOQ} \\
\left(\mu \mathrm{g} \mathrm{g}{ }^{-1}\right)\end{array}$ & $\begin{array}{c}\text { Precision } \\
\text { (as RSD \%) }\end{array}$ \\
\hline Cocaine & 230 & $2.00-100$ & $y=0.9455 x+$ & 1.000 & 0.2 & 0.7 & 2.1 \\
\hline Caffeine & 274 & $2.00-200$ & $\begin{array}{c}y=0.9595 x+ \\
2.967\end{array}$ & 0.998 & 0.3 & 1 & 3.2 \\
\hline Diltiazem & 230 & $2.00-100$ & $\begin{aligned} y= & 1.581 x+ \\
& 2.244\end{aligned}$ & 0.998 & 0.2 & 0.7 & 3.5 \\
\hline Acetaminophen & 248 & $2.00-100$ & $\begin{aligned} y= & 1.125 x+ \\
& 7.712\end{aligned}$ & 0.996 & 0.3 & 1 & 2.1 \\
\hline Fenacetin & 248 & $2.00-200$ & $\begin{aligned} y= & 1.013 x+ \\
& 1.618\end{aligned}$ & 0.999 & 0.2 & 0.7 & 4.1 \\
\hline Lidocaine & 230 & $5.00-200$ & $\begin{aligned} y= & 0.380 x- \\
& 0.848\end{aligned}$ & 0.999 & 0.7 & 2 & 4.1 \\
\hline
\end{tabular}

The precision was estimated as the relative standard deviation (RSD) of six independent analyses of the sample $\mathrm{C}-10$. In this experiment, the sample aliquots were submitted to the whole treatment (dissolution and solid-phase extraction) as described in the experimental section. As can be seen in Table III, the RSD was always lower than $5 \%$.

The accuracy of the method was checked by analyte recovery test, since no certified materials of this kind of sample are commercially available. The analyte recovery test was conducted by spiking the solution obtained from sample C-10. In this case, the sample solution was analyzed with (5.0, 50.0 or $100.0 \mathrm{mg} \mathrm{L}^{-1}$ ) and without analyte spiking. As can be seen in Table IV, excluding two points, the recovery in the range of 94.9 and $110.8 \%$ was achieved. A recovery in the range of $80-120$ is considered ideal for analysis of seized drug [35]. The results of 156.9 for caffeine and $123 \%$ for lidocaine could be considered as outlines.

Table IV. Results obtained in the recovery test of cocaine, caffeine, diltiazem, acetaminophen, phenacetin and lidocaine spiked to solutions of cocaine sample.

\begin{tabular}{|c|c|c|c|c|c|c|c|}
\hline \multirow[b]{3}{*}{ Analyte } & \multirow{3}{*}{$\begin{array}{c}\mathrm{C}_{0} \\
\mathrm{mg} \mathrm{L}^{-1}\end{array}$} & \multicolumn{6}{|c|}{ Concentration found after each addition and recovery (\%) } \\
\hline & & \multicolumn{2}{|c|}{ Addition of $5.00 \mathrm{mg} \mathrm{L}^{-1}$} & \multicolumn{2}{|c|}{ Addition of $50.00 \mathrm{mg} \mathrm{L}^{-1}$} & \multicolumn{2}{|c|}{ Addition of $100.00 \mathrm{mg} \mathrm{L}^{-1}$} \\
\hline & & $\mathrm{mg} \mathrm{L}^{-1}$ & Recovery & $\mathrm{mg} \mathrm{L}^{-1}$ & Recovery & $\mathrm{mg} \mathrm{L}^{-1}$ & Recovery \\
\hline Cocaine & 5.80 & 10.91 & 101 & 59.14 & 106 & 100 & 105.8 \\
\hline Caffeine & 48.00 & 53.53 & 101 & 106.82 & 109 & 106 & 156.9 \\
\hline Diltiazem & 7.60 & 12.18 & 96.7 & 58.75 & 102 & 99.1 & 106.6 \\
\hline Acetaminophen & 17.23 & 22.45 & 101 & 63.80 & 94,9 & 94.5 & 110.8 \\
\hline Phenacetin & 5.32 & 10.21 & 98.9 & 53.22 & 96,2 & 100 & 105.3 \\
\hline Lidocaine & 15.07 & 21.68 & 108 & 64.16 & 98,6 & 107 & 123.1 \\
\hline
\end{tabular}

\section{Development of the GF AAS method for Mn and Pb determination}

A brief study was carried out to set suitable experimental conditions for $\mathrm{Mn}$ and $\mathrm{Pb}$ determination. Firstly, the graphite furnace temperature program was investigated, using the solution obtained by dissolving 50 mg of samples $\mathrm{C}-10$ in $5 \mathrm{~mL}$ of $7 \mathrm{~mol} \mathrm{~L}^{-1} \mathrm{HNO}_{3}$, with subsequent filtration of the solution through a PVDF membrane filter - $13 \mathrm{~mm}$ diameter $0.45 \mu \mathrm{m}$ pore seize sigma. The filtration was needed due a small quantity of insoluble material after the acidic treatment. 
The drying step of the temperature program was maintained as recommended by the manufacturer, since an aqueous solution was introduced into the graphite tube. The general temperature program employed in this work was previously shown in Table I.

The construction of the pyrolysis and atomization temperature curves followed a well know procedure. Firstly, the pyrolysis temperature was varied while the atomization temperature was kept constant. In the case of $\mathrm{Mn}$, the pyrolysis temperature was varied from 200 to $1800{ }^{\circ} \mathrm{C}$, keeping the atomization temperature of $2000^{\circ} \mathrm{C}$. For $\mathrm{Pb}$, the pyrolysis temperature was varied a 200 to $1600^{\circ} \mathrm{C}$, for an atomization temperature at $2200^{\circ} \mathrm{C}$. In order to verify possible interferences of the sample matrix, the pyrolysis and atomization temperature curves were also constructed by analyzing solutions of $\mathrm{Pb}$ and $\mathrm{Mn}$.

The profiles of the pyrolysis and atomization temperature curves are shown in Figure 2. As can be seen in this figure, very similar profiles were obtained for $\mathrm{Mn}$ and $\mathrm{Pb}$ solutions. This behavior was an initial indication that the sample matrix did not interfere in the $\mathrm{Pb}$ and $\mathrm{Mn}$ determination by GFAAS. As a consequence, the pyrolysis and atomization temperatures for $\mathrm{Mn}$ were set at $1400{ }^{\circ} \mathrm{C}$ and $1800{ }^{\circ} \mathrm{C}$, respectively, whereas for $\mathrm{Pb}$ they were $1200^{\circ} \mathrm{C}$ and $2200^{\circ} \mathrm{C}$, respectively.
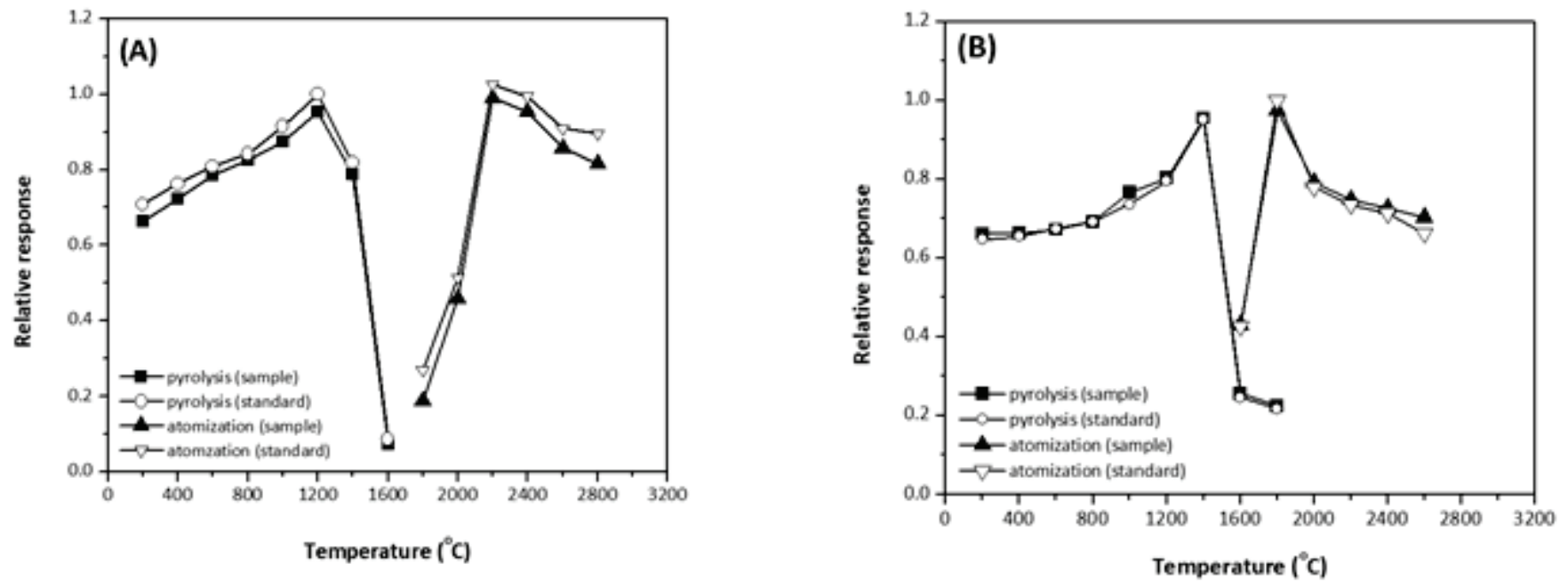

Figure 2. Pyrolysis and atomization temperature curves for $(\mathrm{A}) \mathrm{Pb}$ and $(\mathrm{B}) \mathrm{Mn}$ solution test and sample extract.

In order to confirm that the sample matrix did not interfere in the determination of Mn and Pb by GFAAS, analytical curves prepared from calibration solutions were compared with analyte addition analytical curves. As expected, statistically significant differences were not observed for the slopes of the analytical curves. For $\mathrm{Mn}$, the slope of the analytical curve was $0.054 \pm 0.006 \mathrm{~L}^{-1}\left(\mathrm{r}^{2}=0.992\right)$ and the slope of the analyte addition curve was $0.058 \pm 0.004 \mu^{-1}\left(r^{2}=0.999\right)$. In the case of $\mathrm{Pb}$, the slopes of the analytical and analyte addition curves were $0.0025 \pm 0.003\left(r^{2}=0.998\right)$ and $0.0026 \pm 0.004\left(r^{2}=0.993\right)$, respectively.

In the following step, the LODs and LOQs of the method were calculated, following the 3 (for LOD) and 10 (for LOQ) [34]. The LOD and LOQ were $8 \mathrm{ng} \mathrm{g}^{-1}$ and $28 \mathrm{ng} \mathrm{g}^{-1}$ for $\mathrm{Mn}$, and $20 \mathrm{ng} \mathrm{g}^{-1}$ and $65 \mathrm{ng} \mathrm{g}^{-1}$ for $\mathrm{Pb}$, respectively.

\section{Sample analysis}

The developed methods were then applied to the determination of cocaine, caffeine, diltiazem, acetaminophen, phenacetin, lidocaine, $\mathrm{Mn}$ and $\mathrm{Pb}$ in the samples of seized drugs. The results obtained in the analysis of all 17 samples are presented in Table V. These results are reported already in the concentration found in the drug $(\mathrm{mg} / \mathrm{g}$ or $\mu \mathrm{g} / \mathrm{g}$ ) and not in the aqueous phase. This conversion was made according the extraction steps describe in the preparation of samples procedure. 
Table V. Results of the analyses of cocaine samples seized in the city of Rio de Janeiro, Brazil.

\begin{tabular}{ccccccccc}
\hline & $\begin{array}{c}\text { Caffeine } \\
(\mathbf{m g} / \mathbf{g})\end{array}$ & $\begin{array}{c}\text { Diltiazem } \\
(\mathbf{m g} / \mathbf{g})\end{array}$ & $\begin{array}{c}\text { Acetaminophen } \\
(\mathbf{m g} / \mathbf{g})\end{array}$ & $\begin{array}{c}\text { Phenacetin } \\
(\mathbf{m g} / \mathbf{g})\end{array}$ & $\begin{array}{c}\text { Lidocaine } \\
(\mathbf{m g} / \mathbf{g})\end{array}$ & $\begin{array}{c}\text { Cocaine } \\
(\%)\end{array}$ & $\begin{array}{c}\mathrm{Mn} \\
(\boldsymbol{\mu} \mathbf{g} / \mathbf{g})\end{array}$ & $\begin{array}{c}\mathbf{P b} \\
(\boldsymbol{\mu} / \mathbf{g})\end{array}$ \\
\hline (C_1) & 3.40 & 0.054 & 1.5 & 0.11 & 1.20 & 11.4 & 3.33 & 0.473 \\
\hline (C_2) & 0.038 & 0.042 & 3.4 & 0.10 & 0.92 & 13.5 & 1.37 & 1.60 \\
\hline (C_3) & 3.50 & $<\mathrm{LOQ}$ & 2.8 & 0.18 & 1.50 & 16.7 & 1.39 & 0.310 \\
\hline (C_4) & 0.21 & $<\mathrm{LOQ}$ & 2.1 & 0.45 & 0.74 & 14.7 & 1.17 & 1.48 \\
\hline (C_5) & 0.18 & $<\mathrm{LOQ}$ & 9.6 & 0.51 & $<\mathrm{LOQ}$ & 16.2 & 0.53 & 1.19 \\
\hline (C_6) & $<\mathrm{LOQ}$ & 0.033 & $<\mathrm{LOQ}$ & $<\mathrm{LOQ}$ & 0.56 & 9.20 & 3.97 & 1.67 \\
\hline (C_7) & 4.2 & $<\mathrm{LOQ}$ & $<\mathrm{LOQ}$ & $<\mathrm{LOQ}$ & 1.90 & 9.10 & 1.55 & 2.45 \\
\hline (C_8) & 0.26 & $<\mathrm{LOQ}$ & 3.1 & 0.41 & $<\mathrm{LOQ}$ & 11.2 & 5.56 & 0.213 \\
\hline (C_9) & $<\mathrm{LOQ}$ & $<\mathrm{LOQ}$ & 3 & 0.30 & $<\mathrm{LOQ}$ & 7.20 & 1.12 & 0.193 \\
\hline (C_10) & 1.7 & 0.05 & $<\mathrm{LOQ}$ & $<\mathrm{LOQ}$ & 1.20 & 9.40 & 7.43 & $<\mathrm{LOQ}$ \\
\hline (C_11) & 0.17 & $<\mathrm{LOQ}$ & $<\mathrm{LOQ}$ & $<\mathrm{LOQ}$ & 1.70 & 4.60 & 1.91 & 0.987 \\
\hline (C_12) & 2.1 & $<\mathrm{LOQ}$ & 3 & $<\mathrm{LOQ}$ & 0.48 & 12.6 & 3.83 & 0.108 \\
\hline (C_13) & 1.9 & $<\mathrm{LOQ}$ & 2.7 & $<\mathrm{LOQ}$ & 0.45 & 26.9 & 5.27 & 0.316 \\
\hline (C_14) & $<\mathrm{LOQ}$ & $<\mathrm{LOQ}$ & $<\mathrm{LOQ}$ & $<\mathrm{LOQ}$ & $<\mathrm{LOQ}$ & 28.4 & 1.84 & 0.140 \\
\hline (C_15) & $<\mathrm{LOQ}$ & $<\mathrm{LOQ}$ & $<\mathrm{LOQ}$ & $<\mathrm{LOQ}$ & $<\mathrm{LOQ}$ & 14.2 & 1.54 & 0.128 \\
\hline (C_16) & $<\mathrm{LOQ}$ & $<\mathrm{LOQ}$ & $<\mathrm{LOQ}$ & $<\mathrm{LOQ}$ & $<\mathrm{LOQ}$ & 27 & 1.52 & 0.116 \\
\hline (C_17) & $<\mathrm{LOQ}$ & $<\mathrm{LOQ}$ & $<\mathrm{LOQ}$ & $<\mathrm{LOQ}$ & $<\mathrm{LOQ}$ & 11.4 & $<\mathrm{LOQ}$ & $<\mathrm{LOQ}$ \\
\hline
\end{tabular}

Relatively low concentration of cocaine was found in all samples, indicating that drug dealers have diluted the drug to increase the profit generated by trafficking. This hypothetical procedure has been pointed out in other studies; in the case of Brazil, it was observed that the further from the Brazilian borders the drugs were seized, the greater the dilution factor [11].

The results of the analysis revealed that approximately $80 \%$ of the samples had organic adulterants. Whereas caffeine was the most common found, present in $69 \%$ of the samples.

Manganese and $\mathrm{Pb}$ were investigated because they are present in the reagents used in the process of extraction and refining of cocaine. A strong acid is needed to extract cocaine from the coca plant and, according to police reports [32-33], the $\mathrm{H}_{2} \mathrm{SO}_{4}$ solution used in car batteries, which contains high levels of $\mathrm{Pb}$, is largely employed for that purpose due to the low price of the $\mathrm{H}_{2} \mathrm{SO}_{4}$ solution. Also according to police reports, potassium permanganate solution is used to clarify the cocaine, which is then contaminated with $\mathrm{Mn}$. Of the samples analyzed in this study, $94 \%$ of them contained $\mathrm{Mn}$, whose concentrations ranged from $0.53-7.43 \mathrm{mg} \mathrm{g}^{-1}$. Lead was found in $88 \%$ of samples, in concentrations ranging from $0.108-2.45 \mathrm{mg}$ $\mathrm{g}^{-1}$. This result agrees with other works found in literature dealing with inorganic composition of seized drugs [25,29-30], thus suggesting that the contamination by metal is due reagents used in the extractions steps of the drug.

\section{Drug Profile}

The methods developed in this work gave access to information that could be used to create a chemical signature of the drug (drug profile), which may be useful to differentiate seized drugs. The presence of some components, at certain concentrations, may indicate the way that a given drug has been processed. In this context, the similarity of the chemical profiles of the samples can indicate whether they have a different origin. This information can be obtained by multivariate analysis of the data. To obtain this information, it is still necessary to use an appropriate mathematical tool. In the present case, Hierarquical Cluster Analysis (HCA).

For HCA, the data (concentration of each substance) was normalized to eliminate the effect of the magnitude of the concentrations on the comparation of the standard deviation, which indicates the similarity of the samples. The results of the HCA are given in the dendogram in Figure 3.

According to Figure 3, the samples can be classified into three distinct groups. The first group was composed of the samples C_4, C_5, C_8 and C_9; the second, by samples C_3, C_12, C_13, C_14, C_ 15 and C_16; and the third, by samples C_1, C_2, C_6, C_7, C_10 and C_11. 
This classification was consistent with the physical appearance of the samples and with the information provided by the Police; the samples of the second group showed very similar texture and color and were distinct from the samples classified in groups 1 and 3. Also according to Police information, all samples of the third group were seized from the same dealers.

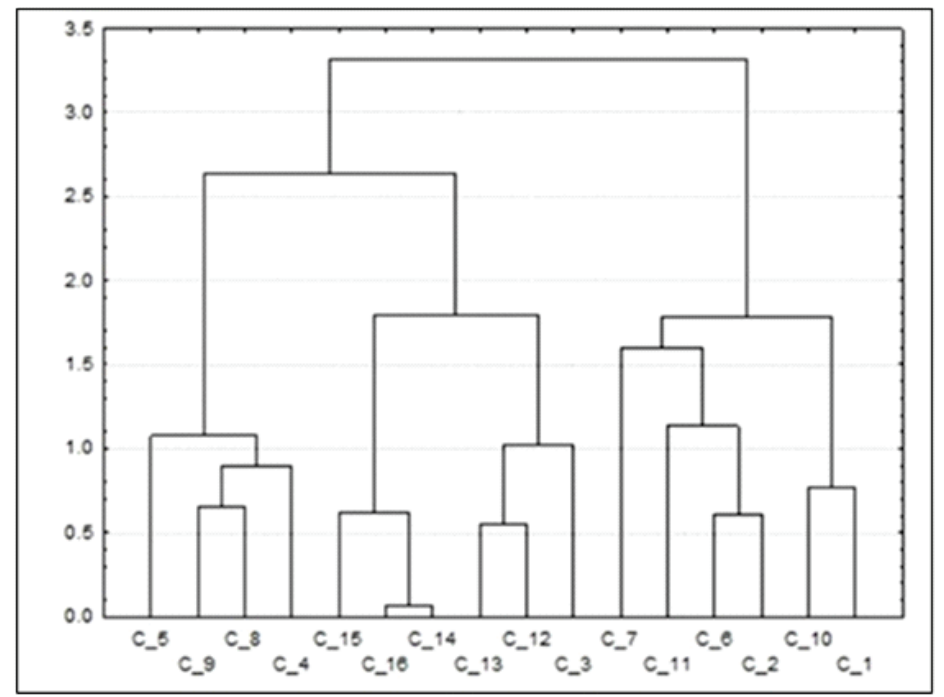

Figure 3. Dendrogram obtained from HCA for the samples of cocaine seized in the city of Rio de Janeiro, Brazil.

\section{CONCLUSIONS}

The developed HPLC-DAD method was suitable for simultaneous quantification of cocaine, caffeine, diltiazem, acetaminophen, phenacetin and lidocaine in seized drug samples. Determination of $\mathrm{Mn}$ and $\mathrm{Pb}$ in the samples was possible by GFAAS, after just dissolving the sample with nitric acid solution.

All samples analyzed contained low concentrations of cocaine (less than $30 \%$ ), indicating that they were diluted before being marketed. In general, the samples (contained at least one adulterant) and caffeine was the most abundant, being found in $69 \%$ of the samples. Almost all samples presented detectable concentrations of manganese and lead.

Multivariate analysis of concentration of contaminants and adulterants can yield a signature of the ilicit drugs, allowing important information regarding their origin and distribution network. An analysis of a larger number of samples (only 17 samples were available in the present study) would enable better classification, and could provide more information about the seized drugs, assisting the intelligence service of the public security forces.

\section{ACKNOWLEDGEMENTS}

The authors would like to thanks the Carlos Chagas Filho Foundation for Research Support of the State of Rio de Janeiro, Brazil (FAPERJ) for the sponsoring of this work.

Manuscript received Oct. 3, 2017; $1^{\text {th }}$ round revised manuscript received Dec. 5, 2017; $2^{\text {nd }}$ round revised manuscript received Feb. 21, 2018; manuscript accepted March 20, 2018. 


\section{Article}

\section{REFERENCES}

1. United Nations Office on Drugs and Crime (UNODC). World Drug Report 2015, 2015. DOI: $10.1017 /$ CBO9781107415324.004.

2. Dowdney, L. Um Estudo de Caso de Crianças em Violência Armada Organizada no Rio de Janeiro. 7Letras, Rio de Janeiro, 2004.

3. Floriani, G.; Gasparetto, J. C.; Pontarolo, R.; Gonçalves, A. G. Forensic Sci. Int. 2014, 235, pp 32-38. DOI: 10.1016/j.forsciint.2013.11.013.

4. Lociciro, S.; Hayoz, P.; Esseiva, P.; Dujourdy, L.; Besacier, F.; Margot, P. Forensic Sci. Int. 2007, 167, pp 220-228. DOI: 10.1016/j.forsciint.2006.06.052.

5. Dujourdy, L.; Besacier, F. Forensic Sci. Int. 2008, 179, pp 111-122.

DOI: 10.1016/j.forsciint.2008.04.024.

6. United Nations Office on Drugs and Crime (UNODC), 'Analysis' 2004. DOI: 10.1007/s12117-9971166-0

7. Morelato, M.; Beavis, A.; Tahtouh, M.; Ribaux, O.; Kirkbride, P.; Roux, C. Forensic Sci. Int. 2013, 226, pp 1-9. DOI: 10.1016/j.forsciint.2013.01.003.

8. Morelato, M.; Beavis, A.; Tahtouh, M.; Ribaux, O.; Kirkbride, P.; Roux, C. Sci. Justice 2014, 54, pp 32-41. DOI: 10.1016/j.scijus.2013.08.006.

9. de Araujo, W. R.; Maldaner, A. O.; Costa, J. L.; Paixão, T. R. L. C.. Microchem. J. 2015, 121, pp 213218. DOI: 10.1016/j.microc.2015.03.012.

10. Kuwayama, K.; Tsujikawa, K.; Miyaguchi, H.; Kanamori, T.; Iwata, Y.; Inoue, H.; Saitoh, S.; Kishi, T. Forensic Sci. Int. 2006, 160, pp 44-52. DOI: 10.1016/j.forsciint.2005.08.013.

11. Perkal, M.; Ng, Y. L.; Pearson, J. R. Forensic Sci. Int. 1994, 69, pp 77-87. DOI: 10.1016/03790738(94)90051-5.

12. Aehle, E.; Dräger, B. J. Chromatogr. B Anal. Technol. Biomed. Life Sci. 2010, 878, pp 1391-1406. DOI: 10.1016/j.jchromb.2010.03.007.

13. Fucci, N.; De Giovanni, N. Forensic Sci. Int. 1998, 95, pp 247-252. DOI: 10.1016/S03790738(98)00102-9.

14. Evrard, I.; Legleye, S.; Cadet-Taïrou, A. Int. J. Drug Policy 2010, 21, pp 399-406. DOI: 10.1016/j.drugpo.2010.03.004.

15. Pagano, B.; Lauri, I.; De Tito, S.; Persico, G.; Chini, M. G.; Malmendal, A.; Novellino, E.; Randazzo, A. Forensic Sci. Int. 2013, 231, pp 120-124. DOI: 10.1016/j.forsciint.2013.04.028.

16. Roy, E.; Richer, I.; Arruda, N.; Vandermeerschen, J.; Bruneau, J. Int. J. Drug Policy 2013, 24, pp 142-149. DOI: 10.1016/j.drugpo.2012.10.004.

17. Ensing, J. G.; Racamy, C.; Zeeuw, R. J. Forensic Sci. 1992, 37, pp 446-459.

18. Moore, J. M.; Casale, J. F.; Klein, R. F. X.; Cooper, D. A.; Lydon, J. J. Chromatog. A 1994, 659, pp 163-175.

19. Della Casa, E.; Martone, G. Forensic Sci. Int. 1986, 32, pp 117-120.

20. Esseiva, P.; Gaste, L.; Alvarez, D.; Anglada, F. Forensic Sci. Int. 2011, 207, pp 27-24. DOI: 10.1016/j.forsciint.2010.08.015. 
21. Goulart, Jr; Santos, S.; Almeida, F. V. Desenvolvimento e Validação de Métodos Cromatográficos para Quantificação de Componentes Majoritários em Amostras de Cocaína, 2012, Master's dissertation, University of Brasilia (UNb).

22. Bernardo, N. P.; Siqueira, M. E. P. B.; De Paiva, M. J. N.; Maia, P. P. Int. J. Drug Policy 2003, 14, pp 331-334. DOI: 10.1016/S0955-3959(03)00083-5.

23. D. G. De Carvalho, A. F. Mídio, Brazilian J. Pharm. Sci. 2003, 39, pp 71-76, DOI: 10.1590/S151693322003000100007.

24. De Oliveira, M. F.; Alves, J. Q.; De Andrade, J. F.; Saczk, A. A.; Okumura, L. L. Eclet. Quim. 2009, 34, pp 77-83. DOI: 10.1590/S0100-46702009000300008.

25. Magalhães, E. J.; Nascentes, C. C.; Pereira, L. S. A.; Guedes, M. L. O.; Lordeiro, R. A.; Auler, L. M. L. A.; Augusti, R.; de Queiroz, M. E. L. R. Sci. Justice 2013, 53, pp 425-432.

DOI: $10.1016 /$ j.scijus.2013.05.003.

26. de Souza, L. M.; Rodrigues, R. R. T.; Santos, H.; Costa, H. B.; Merlo, B. B.; Filgueiras, P. R.; Poppi, R. J.; Vaz, B. G.; Romão, W. Sci. Justice 2016, 56, pp 73-79. DOI: 10.1016/j.scijus.2015.11.006.

27. Lapachinske, S. F.; Okai, G. G.; dos Santos, A.; de Bairros, A. V.; Yonamine, M. Forensic Sci. Int. 2015, 247, pp 48-53. DOI: 10.1016/j.forsciint.2014.11.028.

28. Violante, N.; Quaglia, M. G.; Lopez, A.; Caroli, S. Microchem. J. 1992, 45, pp 79-89. DOI: 10.1016/0026-265X(92)90075-E.

29. Bermejo-Barrera, P.; Moreda-Piñeiro, J. J. Forensic Sci. 1999, 270, pp 44-49.

30. Liu, C.; Hua, Z.; Meng, X. Forensic Sci. Int. 2017, 276, pp 77-84. DOI: 10.1016/j.forsciint.2017.04.014.

31. Almeida, V. G. K.; Cassella, R. J.; Pacheco, W. F. Forensic Sci. Int. 2015, 251, pp 50-55. DOI: 10.1016/j.forsciint.2015.02.014.

32. http://tj-ma.jusbrasil.com.br/jurisprudencia/4816992/revisao-criminal-rvcr-115921999-ma [Assessed on $3^{\text {rd }}$ April, 2017].

33. http://www.akatu.org.br/Temas/Residuos/Posts/Baterias-de-carros-devem-ser-entregues-em-postosde-coleta [Assessed on $3^{\text {rd }}$ April, 2017].

34. Miller, J. C.; Miller, J. N.; Statistics and Chemometrics for Analytical Chemistry, $6^{\text {th }}$ edition, Pearson Education Limited, UK, 2010.

35. United Nations Office on Drugs and Crime (UNODC). Guidance for the Validation of Analytical Methodology and Calibration of Equipment used for Testing of Illicit Drugs in Seized Materials and Biological Specimens. New York, 2009. 